\title{
Erratum: Genotypic and Antimicrobial Susceptibility of Carbapenem-Resistant Acinetobacter baumannii: Analysis of ISAba Elements and blaoxA-23-like Genes Including a New Variant
}

\section{OPEN ACCESS}

Approved by:

Microbiology Editorial Office,

Frontiers, Switzerland

*Correspondence:

Frontiers Production Office production.office@frontiersin.org

Specialty section: This article was submitted to Antimicrobials, Resistance and

Chemotherapy,

a section of the journal

Frontiers in Microbiology

Received: 30 November 2015 Accepted: 30 November 2015 Published: 14 December 2015

Citation:

Frontiers Production Office (2015) Erratum: Genotypic and Antimicrobial

Susceptibility of

Carbapenem-Resistant Acinetobacter baumannii: Analysis of ISAba Elements and blaOXA-23-like Genes Including a New Variant. Front. Microbiol. 6:1430. doi: 10.3389/fmicb.2015.01430
Frontiers Production Office *

Frontiers Production Office, Frontiers, Switzerland

Keywords: Acinetobacter baumannii, bla OXA-23-like gene, carbapenemase, novel mutations

\section{An erratum on}

Genotypic and Antimicrobial Susceptibility of Carbapenem-Resistant Acinetobacter baumannii: Analysis of ISAba Elements and bla OXA-23-like Genes Including a New Variant by Bahador, A., Raoofian, R., Pourakbari, B., Taheri, M., Hashemizadeh, Z., and Hashemi, F. B. (2015). Front. Microbiol. 6:1249. doi: 10.3389/fmicb.2015.01249

Reason for Erratum:

Due to a typesetting error in the title, the ISAba Elements were reported incorrectly as "is $A b a$. " The correct title is: Genotypic and Antimicrobial Susceptibility of Carbapenem-Resistant Acinetobacter baumannii: Analysis of ISAba Elements and bla OXA-23-like Genes Including a New Variant.

The publisher apologizes for this error and the original article has been updated. This error does not change the scientific conclusions of the article in any way.

Copyright $(2015$ Frontiers Production Office. This is an open-access article distributed under the terms of the Creative Commons Attribution License (CC BY). The use, distribution or reproduction in other forums is permitted, provided the original author(s) or licensor are credited and that the original publication in this journal is cited, in accordance with accepted academic practice. No use, distribution or reproduction is permitted which does not comply with these terms. 